\title{
Pengaruh Larutan Madu terhadap Tekanan Darah Lanjut Usia Hipertensi
}

\author{
Siti Aulia Musyayyadah', Joyeti Darni², Fathimah Fathimah ${ }^{3}$ \\ 1,2,3Program Studi Gizi, Universitas Darussalam Gontor, Ngawi, Indonesia \\ Email: auliamusyayy103@gmail.com
}

\begin{abstract}
This study aimed to determine the effect of honey solution intervention on systolic blood pressure and elderly diastole in the Aisyiyah Nursing Home Surakarta. Method of this research using Quasi-experimental approach with a pre-posttest control group design with 24 respondents selected by purposive sampling and divided into 4 groups there are 01 (70 gr honey), O2 (35 gr honey), $K$ - (control with bypertension) and $K+$ (control with normotensive). Measurement of blood pressure using an Omron Sphygmomanometer. Paired Sample T-test was used to determine the effect of blood pressure before and after the intervention. The One Way ANOVA test was used to see differences in the average blood pressure data before the intervention. The results showed that there was an effect of honey solution on systolic blood pressure before and after intervention with $p$ $=0,000(p<0,05)$, as well as diastolic blood pressure in the statistical test, showed that there was an effect of honey solution on blood pressure diastole before and after intervention with $p=$ $0,001(p<0,05)$. So, there was a significant effect on the intervention of honey solution with 35 and $70 \mathrm{gr}$ honey dose on systolic and diastolic blood pressure in the elderly.
\end{abstract}

Keyword: Honey, blood pressure, elderly

\begin{abstract}
Abstrak
Tujuan penelitian ini untuk mengetahui pengaruh intervensi larutan madu terhadap tekanan darah sistolik dan diastolik lanjut usia di Aisyiyah Nursing Home di Surakarta. Jenis penelitian ini adalah kuantitatif menggunakan pendekatan eksperimen semu dengan desain kelompok kontrol pre-posttest dengan 24 responden yang dipilih secara purposive sampling dan dibagi menjadi 4 kelompok yaitu O1 (70 gr madu), O2 (35 gr madu), K- (kontrol dengan hipertensi) dan K + (kontrol dengan normotensif). Pengukuran tekanan darah dengan menggunakan Sphygmomanometer Omron. Uji Paired Sample T-test digunakan untuk mengetahui pengaruh tekanan darah sebelum dan setelah intervensi. Adapun uji One $W$ ay ANOVA digunakan untuk melihat perbedaan rataan data tekanan darah sebelum intervensi. Hasil penelitian menunjukkan adanya pengaruh larutan madu terhadap tekanan darah sistolik sebelum dan sesudah intervensi dengan $p=0,000(\mathrm{p}<0,05)$, serta hasil uji statistik tekanan darah diastolik menunjukkan adanya efek dari larutan madu pada tekanan darah diastolik sebelum dan sesudah intervensi dengan $\mathrm{p}=0,001(\mathrm{p}<0,05)$. Sehingga, terdapat pengaruh yang signifikan terhadap intervensi larutan madu dengan dosis madu 35 dan 70 gr terhadap tekanan darah sistolik dan diastolik pada lansia.
\end{abstract}

Kata Kunci: Madu, tekanan darah, lanjut usia 


\section{PENDAHULUAN}

Hipertensi adalah kondisi peningkatan tekanan darah secara kronis dalam jangka waktu panjang yang jika dibiarkan akan menimbulkan beberapa penyakit degeneratif seperti stroke, aterosklerosis, hingga kematian (Hardinsyah, 2017). Menurut WHO tahun 2013, 45\% kematian karena penyakit jantung disebabkan oleh hipertensi, begitu pula dengan kematian karena stroke mencapai 51\% (WHO, 2013). Prevalensi hipertensi di Indonesia yang didapat melalui pengukuran pada umur $\geq 18$ tahun meningkat menjadi 34,1\% dibandingkan tahun sebelumnya. Kota Surakarta termasuk dalam 10 besar tertinggi hipertensi di Jawa Tengah yaitu pada laki-laki 21,91\% dan perempuan 23,98\% (Kemenkes RI, 2018). Di Panti Jompo Aisyiyah Surakarta didapatkan data bahwa setengah dari populasi lansia mengalami hipertensi dimana rata-rata para lanjut usia sudah memiliki tekanan darah tinggi sebelum masuk panti. Hal ini membuktikan bahwa dengan mengabaikan hipertensi akan meningkatkan kemungkinan komplikasi yang mengancam jiwa.

Hipertensi pada kelompok usia lanjut disebabkan karena adanya perubahan konsistensi pembuluh darah arteri sehingga elastisitas dinding pembuluh darah menurun dan menjadi kaku (Lionakis, 2012). Hal ini juga dipaparkan oleh studi lain bahwa penyebab hipertensi pada lanjut usia yaitu katup jantung yang menebal dan kaku, elastisitas dinding aorta yang menurun, curah jantung menurun, kinerja jantung lebih rentan terhadap pendarahan sehingga terjadi peningkatan tekanan darah (Kenia, 2013). Ciri khas hipertensi pada lanjut usia yaitu tekanan darah sistolik yang mengalami peningkatan hingga diatas $140 \mathrm{mmHg}$ sedangkan tekanan darah diastolik tetap normal yaitu dibawah $90 \mathrm{mmHg}$. Jenis hipertensi seperti ini disebut Isolated Systolic Hypertension (ISH) atau hipertensi sistolik terisolasi (Seke, 2016).

Hipertensi dapat diatasi dengan pengobatan non-farmakologis, salah satunya adalah dengan mengonsumsi madu. Madu berasal dari nektar bunga yang diproses secara alami oleh lebah menjadi suatu cairan manis yang mengandung gula, protein, enzim, vitamin, mineral dan komponen fenolat seperti flavonoid (Arawwawala and Hewageegana, 2017). Madu disebutkan keutamaannya dalam Hadist riwayat Bukhari (As-Sayyid, 2006):

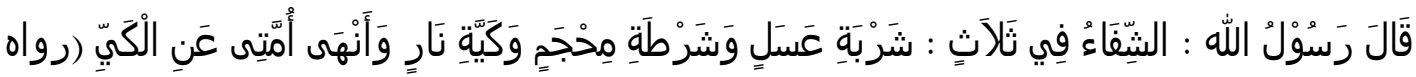

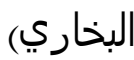

"Sesungguhnya obat itu ada pada tiga perkara yaitu minum madu, berbekam dan ber-kayy dengan api, maka terlaranglah bagi umatku berkayy dengan api itu."

Pada penelitian sebelumnya, pemberian madu setiap hari selama 1 tahun dengan dosis 20 gr dapat menurunkan tekanan darah (Aluko et al., 2014). Penelitian yang dilakukan sebelumnya menunjukkan bahwa pemberian madu 70 gr dapat 
menurunkan kadar glukosa darah puasa dan tekanan darah sistolik-diastolik pada diabetes melitus tipe 2 dengan pemberian 35 gr di pagi hari dan sore hari (Rahma, Bahar and Jafar, 2014). Antioksidan yang terdapat pada madu dapat mengurangi tekanan darah melalui mekanisme vasodilatasi arteri koroner yang memberikan efek hipotensi (Aluko et al., 2014).

Beberapa studi melaporkan bahwa antioksidan yang ada pada madu mampu memperbaiki tekanan oksidatif atau mengurangi peningkatan tekanan darah. Antioksidan adalah suatu senyawa yang mampu menyerap atau menetralisir radikal bebas sehingga dapat mencegah penyakit-penyakit degeneratif seperti kardiovaskuler, karsinogenesis dan lainnya (Arawwawala and Hewageegana, 2017). Pemberian madu yang mengandung antioksidan alami yaitu flavonoid dapat meningkatkan bioavaibilitas nitrit oksida (NO) melalui penangkapan superoksida dalam tubuh sehingga menyebabkan penurunan tekanan darah (Parwata, 2015). Hal ini sesuai dengan pernyataan Davide Grassi pada penelitiannya terkait antioksidan bahwa flavonoid sebagai salah satu jenis antioksidan alami dalam madu dapat meningkatan bioavailabilitas nitrit oksida (NO) dan menurunkan stres oksidatif (Grassi, Desideri and Ferri, 2010).

Tujuan dari penelitian ini adalah untuk mengetahui pengaruh larutan madu terhadap tekanan darah pada lanjut usia di Panti Jompo Aisyiyah Surakarta. Hal yang membedakan dengan penelitian sebelumnya adalah dalam penelitian ini, pemberian madu dicampurkan dengan $150 \mathrm{ml}$ air dan diberikan pada waktu sebelum responden mendapatkan makanan lainnya, sehingga peneliti ingin mengetahui pengaruh madu tanpa ada faktor pengganggu makanan.

\section{METODE}

\section{Desain, Waktu, dan Tempat Penelitian}

Penelitian dilakukan dengan desain penelitian eksperimen semu (Quasy Eksperiment) dengan rancangan control group pre-posttest design. Penelitian dilakukan di Panti Jompo Aisyiyah Solo selama 1 minggu yang dimulai pada tanggal 6-12 Januari 2019. Adapun pemberian air madu dilakukan setiap pukul 11 siang sebelum tiba waktu makan siang.

\section{Populasi dan Sampel Penelitian}

Jumlah populasi yang berada di Panti Jompo Aisyiyah adalah 30 orang. Penentuan sampel menggunakan purposive sampling dengan beberapa kriteria inklusi antara lain: tekanan darah sistolik $\geq 140 \mathrm{mmHg}$ dan tekanan darah diastolik $\geq 90$ $\mathrm{mmHg}$ pada hipertensi tingkat 1 dan tingkat 2, usia 50 tahun keatas, tidak minum obat antihipertensi, berada dalam lingkup asrama, serta mendapat asupan makan dari sumber yang sama. Kriteria eksklusi yaitu wanita lanjut usia yang menderita 
diabetes atau gagal ginjal.

Perolehan jumlah sampel didapat dari hasil perhitungan rumus Federer, dengan besar sampel yang digunakan untuk setiap perlakuannya yaitu 6 sampel. Responden pada penelitian sebanyak 24 orang wanita lansia yang terbagi menjadi 2 kelompok intervensi dan 2 kelompok kontrol. Kelompok intervensi diberikan larutan madu 35 gr dan 70 gr, sedangkan kelompok kontrol diberikan placebo berupa teh dengan pemanis non-calorie.

\section{Pengambilan dan Analisis Data}

Ethical clearance pada penelitian ini didapatkan dari Komisi Etik Penelitian Kesehatan Fakultas Kedokteran Universitas Muhammadiyah Surakarta (UMS) dengan No. 1792/B.1/KEPK-FKUMS/I/2019. Pemeriksaan tekanan darah pada penelitian ini dilakukan pada kelompok intervensi dan kelompok kontrol yang masing-masing sebelum dilakukan intervensi dan dilakukan selama 7 hari setelah diberikan intervensi. Larutan madu diberikan setelah pengukuran tekanan darah yaitu sekitar jam 10 pagi. Pengukuran tekanan darah dilakukan kedua kalinya yaitu 30 menit setelah intervensi larutan madu (Aluko et al., 2014).

Instrumen yang digunakan peneliti untuk mendapatkan hasil pengukuran tekanan darah dengan menggunakan Sphygmomanometer Omron. Uji Paired Sample T-test digunakan untuk mengetahui pengaruh tekanan darah sebelum dan setelah intervensi. Adapun uji One Way ANOVA digunakan untuk melihat perbedaan rataan data tekanan darah sebelum intervensi yang dilanjutkan dengan Post Hoc LSD.

\section{HASIL DAN PEMBAHASAN}

Hasil penelitian yang disajikan pada Tabel 1 menunjukkan bahwa terdapat perbedaan rata-rata tekanan darah sistolik dan diastolik sebelum dan sesudah intervensi larutan madu. Besarnya perbedaan tekanan darah sebelum dan sesudah intervensi dapat dilihat pada rata-rata selisih. Kelompok O1 menunjukkan hasil penurunan tekanan darah sistol dengan selisih terbesar yaitu -30,00. Adapun pada kelompok O2 selisih sebesar -23,33.

Terjadi peningkatan tekanan darah sistolik pada kelompok kontrol, yaitu pada kelompok $\mathrm{K}$ - dengan selisih sebesar 1,33 dan kelompok $\mathrm{K}+$ dengan selisih sebesar 10,67. Adapun penurunan tekanan darah diastolik pada kelompok O1 dengan selisih sebesar -13,33 sedangkan kelompok O2 dengan selisih yang lebih rendah yaitu $-9,17$. Berbeda halnya pada tekanan darah diastolik yang mengalami peningkatan, dengan selisih pada kelompok $\mathrm{K}$ - sebesar 1,00 dan kelompok $\mathrm{K}+$ sebesar 2,50. 
Tabel 1. Hasil Pengukuran Tekanan Darah Sebelum dan Setelah Intervensi Sistolik

\begin{tabular}{lcccc}
\hline \multirow{2}{*}{ Kelompok } & \multicolumn{2}{c}{ Rerata \pm SD } & \multirow{2}{*}{ \pm SD } & Nilai \\
\cline { 2 - 3 } & Sebelum & Setelah & & $\boldsymbol{p}$ \\
\hline O1 & $162,00 \pm 20,50$ & $132,00 \pm 13,93$ & $-30,00 \pm 23,46$ & 0,026 \\
O2 & $154,83 \pm 9,30$ & $131,50 \pm 16,37$ & $-23,33 \pm 14,07$ & 0,010 \\
K- & $148,83 \pm 4,91$ & $150,17 \pm 5,27$ & $1,33 \pm 1,03$ & 0,025 \\
K+ & $111,67 \pm 7,53$ & $122,33 \pm 8,31$ & $10,67 \pm 5,92$ & 0,007 \\
\hline
\end{tabular}

Diastolik

\begin{tabular}{|c|c|c|c|c|}
\hline \multirow{2}{*}{ Kelompok } & \multicolumn{2}{|c|}{ Rerata $\pm S D$} & \multirow{2}{*}{$\Delta \pm \mathrm{SD}$} & \multirow{2}{*}{$\begin{array}{c}\text { Nilai } \\
p\end{array}$} \\
\hline & Sebelum & Setelah & & \\
\hline O1 & $96,83 \pm 11,27$ & $83,50 \pm 3,62$ & $-13,33 \pm 10,83$ & 0,030 \\
\hline $\mathrm{O} 2$ & $90,33 \pm 12,36$ & $81,17 \pm 9,17$ & $-9,17 \pm 4,58$ & 0,004 \\
\hline K- & $83,67 \pm 9,85$ & $84,67 \pm 9,65$ & $1,00 \pm 1,41$ & 0,144 \\
\hline $\mathrm{K}+$ & $71,33 \pm 5,99$ & $73,83 \pm 3,43$ & $2,50 \pm 5,32$ & 0,302 \\
\hline
\end{tabular}

Keterangan:

$\mathrm{O} 1=$ Kelompok intervensi larutan madu dengan dosis madu murni $70 \mathrm{gr}$

O2 $=$ Kelompok intervensi larutan madu dengan dosis madu murni $35 \mathrm{gr}$

$\mathrm{K}-\quad=$ Kelompok kontrol dengan normotensi

$\mathrm{K}+\quad=$ Kelompok kontrol dengan hipertensi

Dosis madu yang digunakan dalam penelitian ini serupa dengan penelitian yang dilakukan oleh Nurhaedar bahwa intervensi madu sebanyak 70 gr per hari pada penderita DM tipe 2 menunjukkan kestabilan tekanan darah (Jafar, 2013). Tekanan darah pada lansia yang diberikan larutan madu cenderung mengalami penurunan dibandingkan dengan lansia yang tidak diberikan larutan madu. Hal ini sejalan dengan hasil penelitian sebelumnya yang menyatakan bahwa terdapat pengaruh yang signifikan antara sebelum dan setelah diberikan terapi madu $20 \mathrm{gr}$ secara oral pada penderita hipertensi di wilayah kerja UPK Puskesmas Pontianak (Aini, 2015). Penurunan tekanan darah setelah intervensi madu juga dipaparkan oleh Aluko dan Helen dalam penelitiannya terhadap orang sehat, dimana $20 \mathrm{gr}$ madu memberikan pengaruh terhadap penurunan tekanan darah pada menit ke 15 , 30 dan 60 setelah meminum madu (Aluko et al., 2014). Adapun penelitian yang dilakukan terhadap tikus hipertensi bahwa terjadi penurunan tekanan darah sistol setelah pemberian madu (Erejuwa et al., 2012). 


\section{Tabel 2. Pengaruh Intervensi terhadap Tekanan Darah}

\begin{tabular}{lcccc}
\hline & \multicolumn{2}{c}{ Sistolik } & \multicolumn{2}{c}{ Diastolik } \\
\cline { 2 - 5 } Kelompok & $\boldsymbol{\Delta} \pm \mathrm{SD}$ & $\mathbf{N i l a i}$ & $\boldsymbol{\Delta} \pm \mathbf{S D}$ & Nilai \\
& & $\boldsymbol{p}$ & & $\boldsymbol{p}$ \\
\hline $\mathrm{O} 1$ & $-30,00 \pm 23,46$ & 0,000 & $-13,33 \pm 10,83$ & 0,001 \\
$\mathrm{O} 2$ & $-23,33 \pm 14,07$ & & $-9,17 \pm 4,58$ & \\
$\mathrm{~K}-$ & $1,33 \pm 1,03$ & & $1,33 \pm 1,03$ & \\
$\mathrm{~K}+$ & $10,67 \pm 5,92$ & & $5,17 \pm 1,94$ & \\
\hline
\end{tabular}

Hasil uji statistik menunjukkan terdapat perbedaan tekanan darah sistolik dan diastolik setelah intervensi larutan madu dengan nilai $p<0,05$. Artinya, bahwa intervensi larutan madu dengan berbagai dosis secara signifikan dapat menurunkan tekanan darah sistolik dan diastolik terhadap semua kelompok. Penurunan tekanan darah pada lansia setelah intervensi larutan madu juga disebabkan oleh kandungan vitamin $\mathrm{C}$ dalam madu. Larutan madu pada penelitian ini dibuat menggunakan air bersuhu normal. Hal ini dikarenakan vitamin $C$ yang terdapat di dalam madu memiliki sifat yang mudah teroksidasi bila bersentuhan dengan panas (Almatsier, 2009). Hal ini serupa dengan penelitian sebelumnya, dimana kandungan Vitamin C dapat menurunkan tekanan darah sistolik tikus yang diinduksi $\mathrm{NaCl} 8 \%$ (Husna, Damayanti and Sari, 2019).

Vitamin C merupakan salah satu antioksidan larut air berperan dalam memberikan perlindungan terhadap sel endotelial dengan meningkatkan ketersediaan NO (Nitric Oxide) sebagai antihipertensi (Grober, 2015). Sebagian pasien hipertensi, gangguan kemampuan vasodilatasi disebabkan oleh kekurangan NO pada dinding pembuluh darah (Sherwood, 2013). Vitamin C mampu melindungi NO dari proses oksidasi sehingga bioavailalibitas NO meningkat dan tekanan darah menurun. Peningkatan NO akan mengurangi fosforilasi miosin sehingga ikatan aktin dan miosin akan terlepas dan menyebabkan relaksasi dinding pembuluh darah sehingga tekanan darah menurun (Sherwood, 2013).

Berdasarkan hasil uji statistik menunjukkan bahwa terdapat perbedaan signifikan tekanan darah sistolik antara kelompok O1 dengan kelompok kontrol $(\mathrm{K}$ - dan $\mathrm{K}+$ ) dengan $\mathrm{p}<0,05$. Hasil uji statistik juga menunjukkan terdapat perbedaan tekanan darah sistolik antara kelompok $\mathrm{O} 2$ dengan kelompok kontrol $(\mathrm{K}$ - dan $\mathrm{K}+$ ) dengan $\mathrm{p}<0,05$. Merujuk pada hasil uji statistik, maka terdapat perbedaan yang bermakna pada tekanan darah sistolik setelah intervensi larutan dengan dosis madu 70 gr dan 35 gr terhadap seluruh kelompok. Namun, tidak terdapat perbedaan intervensi larutan madu antara kedua dosis, yaitu antara kelompok $\mathrm{O} 1$ dan $\mathrm{O} 2$ dengan $\mathrm{p}>0,05$. 
Tabel 3. Pengaruh Intervensi Larutan Madu terhadap Tekanan Darah

\begin{tabular}{|c|c|c|c|}
\hline \multirow{3}{*}{ Kelompok } & & \multicolumn{2}{|c|}{ Nilai } \\
\hline & & \multicolumn{2}{|c|}{$P$} \\
\hline & & Sistolik & Diastolik \\
\hline \multirow[t]{3}{*}{ O1 } & $\mathrm{O} 2$ & 0,419 & 0,280 \\
\hline & K- & 0,001 & 0,001 \\
\hline & $\mathrm{K}+$ & 0,000 & 0,000 \\
\hline \multirow[t]{2}{*}{$\mathrm{O} 2$} & $\mathrm{~K}-$ & 0,006 & 0,013 \\
\hline & $\mathrm{K}+$ & 0,000 & 0,006 \\
\hline K- & $\mathrm{K}+$ & 0,262 & 0,693 \\
\hline
\end{tabular}

Komponen fenolat total dalam madu berkisar antara $370-1190 \mathrm{mg} / 100 \mathrm{ml}$ dimana terdapat 9 jenis komponen fenolat diantaranya adalah flavonoid (Chayati, 2014). Hal ini sejalan dengan penelitian sebelumnya mengenai jumlah komponen fenolat totalnya 1296,25 mg/100 g pada jus belimbing manis yang berpengaruh pada hipertensi (Arza and Irawan, 2018). Kadar flavonoid dalam madu yang berkisar antara 3,80-33,46 mg/100 gr berbanding lurus dengan aktifitas antioksidan (Chayati, 2014). Hal tersebut sejalan dengan penelitian sebelumnya yang menjelaskan kandungan flavonoid yang memberikan efek penurunan tekanan darah dan mengembalikan fungsi endotel pada hewan uji yang mengalami hipertensi (Sariningsih and Srimiati, 2018). Flavonoid juga dapat menghambat aktivitas Angiotensin I Converting Enzyme (ACE) dalam membentuk angiotensin II yang menjadi penyebab penyempitan pada pembuluh darah (Nadila, 2014) .

\section{KESIMPULAN}

Berdasarkan hasil penelitian, terdapat pengaruh yang signifikan dari intervensi larutan madu dengan dosis madu 35 dan 70 gr terhadap tekanan darah sistolik dan diastolik pada lansia. Pada penelitian ini, peneliti belum menyertakan argumentasi terkait asupan makanan dikarenakan tidak adanya catatan riwayat makan pasien. Penelitian selanjutnya sebaiknya menyertakan catatan hasil food recall 24 jam pasien sebagai kontrol terhadap faktor eksternal.

\section{UCAPAN TERIMA KASIH}

Peneliti sangat berterima kasih kepada para koordinator Panti Jompo Aisyiyah Surakarta yang telah mendukung penelitian ini sehingga dapat berjalan sebagaimana mestinya. 


\section{DAFTAR PUSTAKA}

Aini, R. (2015) 'Pengaruh pemberian madu terhadap perubahan tekanan darah pada penderita hipertensi di wilayah kerja upk puskesmas khatulistiwa kecamatan pontianak utara', JURNAL PRONERS, 3(1).

Almatsier, S. (2009) Prinsip Dasar Ilmu Gizi, PT Gramedia Pustaka Utama, Jakarta.

Aluko, E. O. et al. (2014) 'Honey's ability to reduce blood pressure and heart rate in healthy male subjects', Frontiers in Science, 4(1), pp. 8-11. doi: 10.5923/j.fs.20140401.02.

Arawwawala, M. and Hewageegana, S. (2017) 'Health benefits and traditional uses of honey: A review', Journal of Apitherapy, 2(1), pp. 9-14. doi: $10.5455 /$ ja.20170208043727.

Arza, P. A. and Irawan, A. (2018) 'Pengaruh pemberian jus averrhoa carambola terhadap penurunan tekanan darah pada lansia penderita hipertensi', Jurnal Kesehatan, 9(1), pp. 51-56. doi: 10.26630/jk.v9i1.742.

As-Sayyid, A. B. M. (2006) Rasulullah's Diet: Healthy Food in Qur'an and Sunnah. 1st edn. Edited by Y. Muthalib. Jakarta: Almahira.

Chayati, I. (2014) 'Study of phenolic compounts, total phenolic, and antioxidant activities of monofloral honeys from some areas in Java and Sumatera', MGMI Journal, 6, pp. 11-24.

Erejuwa, O. O. et al. (2012) 'Honey supplementation in spontaneously hypertensive rats elicits antihypertensive effect via amelioration of renal oxidative stress', Oxidative Medicine and Cellular Longevity. Edited by F. Lang. Hindawi Publishing Corporation, 2012, pp. 1-14. doi: 10.1155/2012/374037.

Grassi, D., Desideri, G. and Ferri, C. (2010) 'Flavonoids: Antioxidants against atherosclerosis', Nutrients, 2(8), pp. 889-902. doi: 10.3390/nu2080889.

Grober, U. (2015) Micronutrients: Metabolic puning-prevention-therapy. Jakarta: Medical Book Publisher of EGC.

Hardinsyah (2017) Ilmu Gizi : Teori dan Aplikasi. Jakarta: Medical Book Publisher of EGC.

Husna, F., Damayanti, A. Y. and Sari, D. D. (2019) 'Perbandingan efek antihipertensi jus ciplukan, mentimun, dan kombinasi ciplukan mentimun terhadap tekanan darah sistolik tikus yang diinduksi nacl 8\%, Nutri-Sains: Jurnal Gizi, Pangan dan Aplikasinya, 3(1), pp. 43-51.

Jafar, N. (2013) 'Effect of pure honey intake on fasting blood glucose patient with type 2 mellitus diabetic using glibenclamide or metformin therapy', (33).

Kemenkes RI (2018) Hasil Utama Riskesdas 2018. Jakarta (ID): Kemenkes RI.

Kenia, N. M. (2013) 'Effect of relaxation (rose aromatherapy) towards blood pressure change of the elderly with', STIKES journal, 6(1), pp. 84-98.

Lionakis, N. (2012) 'Hypertension in the elderly', World Journal of Cardiology, 4(5), pp. 
135-147. doi: 10.4330/wjc.v4.i5.135.

Nadila, F. (2014) 'Antihypertensive potential of chayote fruit extract kandungan labu siam potensi flavonoid', Medical Journal of Lampung University, 3, pp. 34-38.

Parwata, I. M. (2015) 'Teaching book of bioactivity test of antioxidant', pp. 1-51.

Rahma, A. S., Bahar, B. and Jafar, N. (2014) 'Honey in reducing blood pressure and hematological parameter'.

Sariningsih, E. and Srimiati, M. (2018) 'Formulasi jus alpukat dengan air kelapa muda yang berpotensi menurunkan hipertensi', Nutri-Sains: Jurnal Giri, Pangan dan Aplikasinya, 2(1), pp. 24-33.

Seke, P. (2016) 'Relation of Stress Factor with Hypertension on Elderly at Senja Cerah Nursing Home Mapanget District Manado', 4, pp. 1-5.

Sherwood, L. (2013) Introduction to buman physiolog. 8th edn. Jakarta: Medical Book Publisher of EGC.

WHO (2013) 'A global brief on Hyper - tension World Health Day 2013’. 
Halaman ini sengaja dikosongkan 